Article

\title{
Legal Provisions and Market Conditions for Energy Communities in Austria, Germany, Greece, Italy, Spain, and Turkey: A Comparative Assessment
}

\author{
Mehmet Efe Biresselioglu ${ }^{1, *}$, Siyami Alp Limoncuoglu ${ }^{2}$, Muhittin Hakan Demir ${ }^{3}{ }^{\circledR}$, Johannes Reichl ${ }^{4}$, \\ Katrin Burgstaller ${ }^{4}$, Alessandro Sciullo ${ }^{5}$ and Edoardo Ferrero ${ }^{6}$ \\ 1 Sustainable Energy Division, Izmir University of Economics, Izmir 35330, Turkey \\ 2 Faculty of Law, Izmir University of Economics, Izmir 35330, Turkey; alp.limoncuoglu@ieu.edu.tr \\ Department of Logistics Management, Izmir University of Economics, Izmir 35330, Turkey; \\ muhittin.demir@ieu.edu.tr \\ 4 The Energy Institute, Johannes Kepler University, 4040 Linz, Austria; reichl@energieinstitut-linz.at (J.R.); \\ burgstaller@energieinstitut-linz.at (K.B.) \\ 5 Department of Culture, Politics, and Society, University of Turin, 10124 Turin, Italy; \\ alessandro.sciullo@unito.it \\ 6 Department of Law, University of Turin, 10124 Turin, Italy; edoardo.ferrero@unito.it \\ * Correspondence: efe.biresselioglu@ieu.edu.tr
}

Citation: Biresselioglu, M.E.; Limoncuoglu, S.A.; Demir, M.H.; Reichl, J.; Burgstaller, K.; Sciullo, A.; Ferrero, E. Legal Provisions and Market Conditions for Energy Communities in Austria, Germany, Greece, Italy, Spain, and Turkey: A Comparative Assessment. Sustainability 2021, 13, 11212. https:// doi.org/10.3390/su132011212

Academic Editor: Grigorios

L. Kyriakopoulos

Received: 31 August 2021

Accepted: 6 October 2021

Published: 11 October 2021

Publisher's Note: MDPI stays neutral with regard to jurisdictional claims in published maps and institutional affiliations.

Copyright: (c) 2021 by the authors. Licensee MDPI, Basel, Switzerland. This article is an open access article distributed under the terms and conditions of the Creative Commons Attribution (CC BY) license (https:// creativecommons.org/licenses/by/ $4.0 /)$

\begin{abstract}
The Climate Pact and the European Green Deal constitute the main components of the European Union (EU)'s climate change policy. Energy transition, that is, transformation to a zerocarbon global energy system, is one of the main pillars of climate change mitigation policies. This transformation, coupled with the empowerment of individuals within the energy system, shifts citizens from their roles as customers towards a more active role. Within this framework, energy communities stand out as significant facilitators for the participation of individuals and communities in the energy system, promoting self-consumption and contributing to the social acceptance of renewable energy initiatives, among other direct and indirect benefits. The main directives introducing energy communities into the EU legal system are RED II and ED 2019. This study, conducted as a part of a Horizon 2020-funded eCREW project, assessed the adaptability and implementability of these two directives within national legislation, along with the associated legal and administrative frameworks, utilizing evidence from Austria, Germany, Greece, Italy, Spain, and Turkey. The comparative analysis also enhances the understanding of the concept of renewable energy communities and citizen energy communities, both in the EU and in nonmember countries. The results of the analysis revealed that none of the countries studied had yet completed the process of harmonizing their legislation concerning energy communities.
\end{abstract}

Keywords: climate change; climate pact; European Union; Green Deal; energy communities; RED II; ED 2019

\section{Introduction}

Climate change is one of the main global challenges of the contemporary era. Fossil fuels are still the most commonly used energy source, accounting for around $80 \%$ of primary energy generation, and GHG (greenhouse gas) emissions constitute a major factor in climate change. In an attempt to slow or mitigate the effects of climate change, governments are seeking guidance on adopting policies and action plans, such as through the international Paris Agreement, the European Union (EU)-wide Climate Pact, or the European Green Deal [1]. The latter targets zero net GHG emissions for Europe by 2050 [2].

A major pillar of climate change mitigation is energy transition, which means transformation to a zero-carbon global energy system. The scope of energy transition also covers the transition to a low-carbon economy and society in which renewable energy 
systems are of particular importance [1,3]. The three main focal areas of energy transition have been identified as smart energy systems, market mechanisms, and policy and information technology support [4]. Climate-related and energy transition targets are not the sole responsibility of governments; carbon-emitting industries are expected to take action in order to decrease their impacts, and citizens, to adopt more climate-friendly lifestyles. The transformation of the energy system as part of energy transition, along with the empowerment of individuals, shifts citizens from their long-assumed customer roles to more active roles, such as prosumers [5]. In Europe, by 2050, more than 260 million citizens are expected to become players in the energy market as prosumers, accounting for $45 \%$ of renewable energy generation and thereby becoming a major component of energy transition and climate change mitigation [6].

Within this context, energy communities play a significant role in facilitating citizens ${ }^{\prime}$ participation in the energy system. In energy communities, a new concept, citizens and enterprises join forces in collective energy initiatives, generally aiming to produce members' energy needs using renewable sources. The energy market structure, as well as the associated legal, administrative, and social infrastructures, are among the main factors facilitating the establishment, operation, and development of energy communities.

As well as contributing to energy transition, energy communities also offer an avenue for the active participation of individuals and communities within the energy system. This allows individuals and communities to organize themselves into energy initiatives, which promotes self-consumption. Moreover, energy communities contribute to the social acceptance of renewable energy initiatives [7]. Individuals and communities also enjoy the direct and indirect benefits of energy communities, such as lower energy costs, incentives, supply tariffs, higher energy efficiency, and reduced consumption. The formal aspect of energy communities supports communities' involvement in business activities by corporate energy market players. Energy communities also enhance the implementation of demand response schemes and energy storage technologies, thereby contributing to energy systems and their flexibility and reducing the capacity needed.

The EU has taken significant steps in terms of establishing the legal framework for initiatives such as energy communities. The Clean Energy for all Europeans package (CEP) of 2018 [8], regarding the redesign of the electricity market, involves specific references to energy transition as well as relevant community and citizen activities. The CEP paves the way for individuals to participate in electricity trade through roles including prosumers and energy communities. CEP allows individuals and communities to generate, consume, share, or sell electricity and mandates that the member states take necessary actions towards a more flexible and competitive electricity market that is also customercentered and nondiscriminatory [5]. Member states are expected to transpose and adopt the CEP into their national legislation, specifically, the Renewable Energy Directive (RED II) 2018/2001/EU [9] and the Energy Market Directive (ED 2019) 2019/944 [10]. RED II introduces the concept of renewable energy communities (RECs), and ED 2019, the concept of citizen energy communities (CECs).

The main determinants of the implementability of energy communities are the legislation in a country and the state of adoption of RED II and ED 2019. However, REC s' and CECs' feasibility and implementability are also impacted by uncertainties in legal and administrative infrastructure, challenges with bureaucracy, technical capacity, administrative departments' skill and information levels, the structure of the energy market, the maturity of the electricity market, and tariff schemes.

To this end, this manuscript presents the results of research conducted as a part of a Horizon 2020-funded eCREW project under Work Package 5 that aimed to contribute to the literature related to the status of RED II and ED 2019 in national legislation, along with the associated legal and administrative frameworks and other relevant factors, utilizing evidence from Austria, Germany, Greece, Italy, Spain, and Turkey. The research showed that on the one hand, not all countries have yet introduced RECs and CECs into their legal frameworks, and on the other, opportunities to form energy communities already 
existed before the directives came into force. It also became apparent that not all countries have yet completed the rollout of smart meters. This contribution provides an actual and transnational review of six national regulations for joint generation of electricity in the framework of energy communities.

Energy markets vary in size and maturity and have different levels of capacity and capability to transpose the directives into national legislation. In addition, directives stipulate the mandatory objectives for each member state, which could result in differences in national implementations. Therefore, an assessment of this diverse set of countries can create a greater depth of understanding of the concept of renewable energy communities and citizen energy communities in the EU and nonmember countries.

The article presents the literature review in Section 2 and the three-phase approach to the research in Section 3. This is followed by analysis of RED II and ED 2019 in Section 4 and the concept of energy communities in Section 5. Section 6 deals with the current status of the adoption of RED II and ED 2019 into the national legal frameworks of the six selected countries. The conclusion of this manuscript is presented in Section 7.

\section{Literature Review}

The decentralization of the energy market entered the European agenda in the 1990s [11,12]. The first energy package of the EU, adopted in 1996 (Directive 96/92/EC), contained provisions for the liberalization of the energy markets [13]. The Directive permitted third-party access and functional bundling [14]. The second energy package, adopted in 2013 (Directive 2003/54/EC, Directive 2003/55/EC, and Regulation (EC) No 1228/2003), aimed at securing the independence of market regulatory bodies and competitive retail market [15]. The third energy package (Directive 2009/72/EC, Directive 2009/73/EC, Regulation (EC) No 713/2009, Regulation (EC) No 714/2009 and Regulation (EC) No $715 / 2009$ ) contributed to the liberalization of the energy markets by clarifying the existing rules on unbundling of network operators, increasing the independence of National Regulatory Agencies and establishing ACER (EU Agency for the Cooperation of Energy Regulators) [14,16]. More recently, the Clean Energy Package, which includes the Directives that regulate energy communities (Renewable Energy Directive (RED II) 2018/2001/EU and Internal Electricity Market Directive (ED 2019) 2019/944), entitled consumers the rights of traditional market players in participating in the energy markets and eliminated all administrative, technical, and financial barriers to establishing collective energy initiatives (i.e., citizen energy communities and renewable energy communities) [17].

The first examples of community-based energy generation were experienced in Denmark and the UK during the last decade of the 20th century [18-21]. These collective initiatives were termed as "community renewables" [18]. The terms "community energy groups" and "renewable energy (source) cooperatives" were also used, mainly in academic studies [22-24].

Existing literature has identified the benefits, and the need for an adequate definition, of the energy community concept $[25,26]$. The most cited definition in the existing literature described energy communities as "projects where communities (of place or interest) exhibit a high degree of ownership and control", while the main aspect of "community energy" was "benefiting collectively from the outcomes" (either energy-saving or revenuegeneration) [27]. However, there has been no common agreement on the definition of "energy community" as yet [28,29].

In the literature, four main types of energy communities have been identified: (1) placebased with single-purpose form, (2) place-based with multipurpose form, (3) non-placebased with single-purpose form, and (4) non-place-based with multipurpose form [30,31]. Non-place-based energy communities are those that any person can join, regardless of location. The members of place-based energy communities, on the other hand, are residents of a specific location (such as a district, neighbourhood, or tower block). Single-purpose energy communities aim solely to generate and consume energy; whereas multipurpose energy communities are established to operate on a wider range of energy market activities, 
such as storage, distribution, supply, and providing services. Table 1 summarizes the different types of energy communities [30].

Table 1. The different types of energy communities [30].

\begin{tabular}{ccc}
\hline Single-purpose & $\begin{array}{c}\text { Established exclusively for the } \\
\text { production, management, and } \\
\text { purchasing energy, abiding shared } \\
\text { rules. Members can be from any } \\
\text { location }\end{array}$ & $\begin{array}{c}\text { Established exclusively for the } \\
\text { production, management, and } \\
\text { purchasing energy, abiding shared } \\
\text { rules. Members need to be from a } \\
\text { specific location }\end{array}$ \\
\hline Multipurpose & $\begin{array}{c}\text { Can carry out the production, } \\
\text { management, and purchasing of } \\
\text { energy, other commodities and } \\
\text { services, abiding shared rules. } \\
\text { Members can be from any location }\end{array}$ & $\begin{array}{c}\text { Can carry out the production, } \\
\text { management, and purchasing of } \\
\text { energy, other commodities and } \\
\text { services, abiding shared rules. } \\
\text { Members need to be from a specific } \\
\text { location }\end{array}$ \\
\hline
\end{tabular}

Energy communities can take many legal forms, such as cooperatives, limited partnerships, and foundations [19,26,32-35]. As countries are generally used to a more conservative energy market and historically prefer centralized management, cooperatives are the currently most common type, since they allow for a centralized ownership system $[26,33,36]$. As of 2018, more than 2500 energy cooperatives were established in just four European countries (Austria, Denmark, Germany, and the United Kingdom) [37]. By 2020, the estimated number of renewable energy cooperatives across Europe was nearly 3500 [33].

Individuals tend to join energy communities for several reasons. The main motivation seems to be environmental concerns [19]. Since climate change has long been on most countries' agendas, citizens and governments are willing to support energy communities based on an overall perception that associates energy communities with clean energy [38-41]. Financial or economic reasons are also among drivers [39-41]; members of energy communities may benefit from return on investments, lower energy prices, and energy efficiency measures [42]. Social drivers of joining energy communities have also emphasized in the literature, such as social approval, social identity, and solidarity, and are affected by the specific social environment [42-44].

A number of studies in the literature have emphasized the positive impacts of decentralization of the energy markets and the establishment of energy communities on the transition of the energy markets and provision of energy justice [26,31,45-47]. Community-based collective energy initiatives have been regarded as fundamental actors in the transition of the energy market towards a low carbon economy $[21,26,31,36,48]$. The financial power of the community, however, may be at risk when competing with big, conservative market players. Moreover, the financial burden of the transition is not distributed proportionally; the higher impact on low-income households [49] threatens energy poverty [50]. Financial concerns constitute a serious barrier to the decision to join energy communities. This barrier, however, may be overcome with effective financial incentive schemes [20,31,51]. Bureaucracy and legal and administrative barriers also hinder increasing the participation to energy communities [32]. For many years, energy markets were centralized and highly regulated. Because of particular implementations of this centralized setting still in effect, becoming a market player may require obtaining an official licence from the national energy authority. Often, the cumbersome required procedures constitute serious constraints for relatively small entrepreneurs to exist and operate in the market $[25,52,53]$. In many cases, the types of market players are defined explicitly by legislation, preventing other entities of different legal forms to do business in the energy market $[54,55]$.

Another line of research has concentrated on categorizing the barriers to individuals participation. Brummer, for instance, following up Weber's structure of barrier models [56], 
determined six different categories: (a) organizational issues, legal framework, and planning requirements; (b) discrimination by big companies to preserve their positions in the market; (c) lack of institutional and political support; (d) scepticism about community energy, together with NIMBY opposition; (e) lack of resources, expertise, and resilience; and (f) saturation effect [57]. A relatively recent study, the Newcomers Project, identified four main categories of barriers: (a) in socio-economic conditions, (b) in technical systems, (c) in institutional settings, and (d) in market actors [58].

\section{Conceptual Framework of Research}

The study had a three-phase methodological framework.

The first phase was designed to establish the groundwork for the analysis. In this phase, there was an assessment of the main aspects of two directives, RED II and ED 2019, that were focal to this study. This phase also involved a comparative analysis for another pillar of the research, CECs and RECs. Finally, the literature review aligned these two pillars with relevant studies in the literature.

The second phase of the methodological framework involved, as the first step, the selection of countries and criteria for the assessment of adaptability regarding RED II and ED 2019. The second step was the fundamental analysis, including a comparative analysis for the selected countries.

The third phase synthesized the findings from the first two phases for an overall assessment of the status of the implementation of RED II and ED 2019 into national legislation of EU member states and Turkey's preparedness for a similar approach to energy communities. The main dimensions exploited in this step were legal frameworks, administrative frameworks, and energy markets. The three phases were supported by legal research methods, which involved consulting in-force provisions and explanatory notes on legislation and literature. Figure 1 below depicts the conceptual framework of the present research.
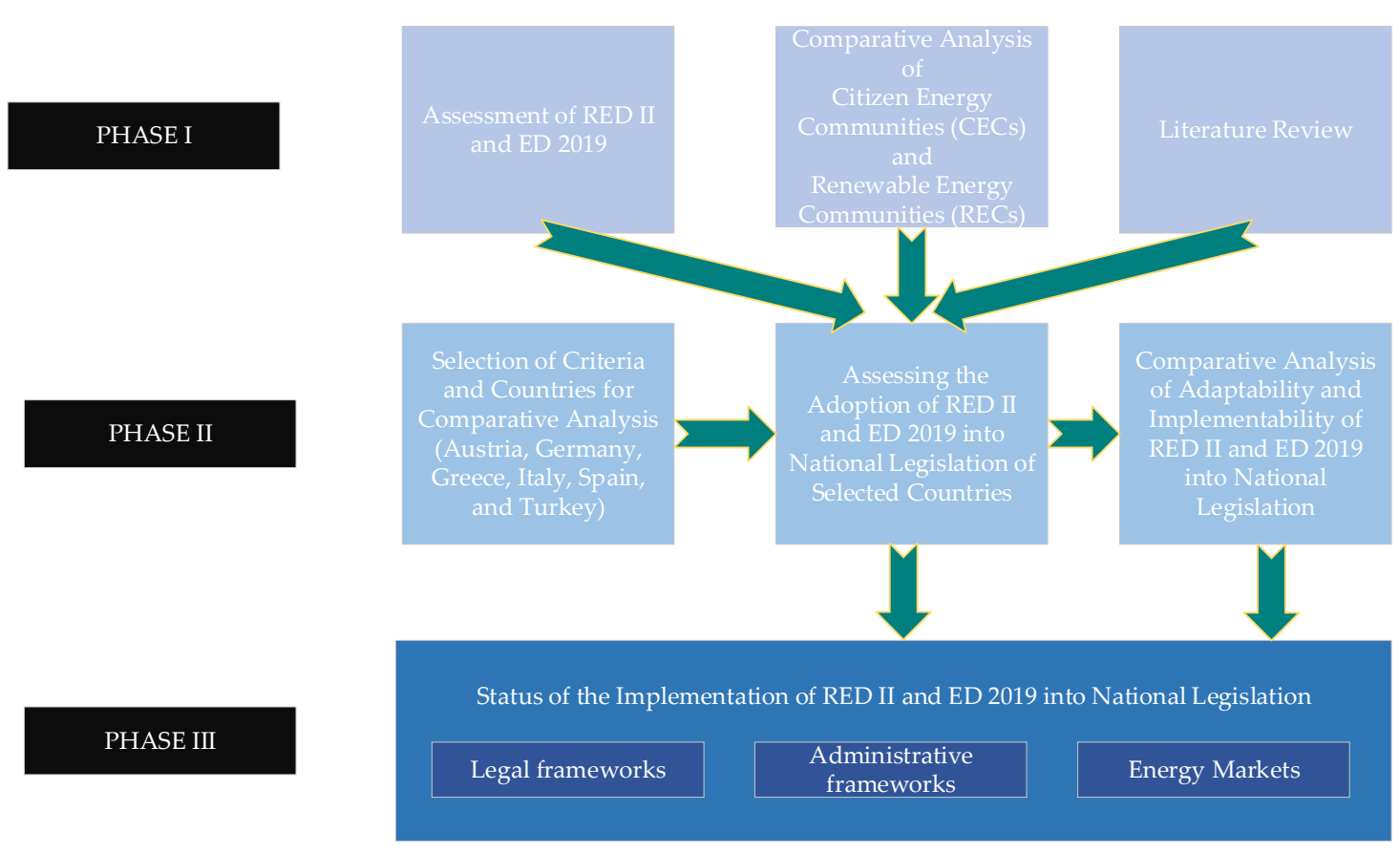

Figure 1. The conceptual framework of the present research (illustrated by authors). 


\section{Assessing the Renewable Energy Directive (RED II) 2018/2001/EU and Internal Electricity Market Directive (ED 2019) 2019/944 Based on State-of-the-Art Literature \\ 4.1. Renewable Energy Directive (RED II) 2018/2001/EU}

The use of clean energy is a major EU energy policy goal [59]. The package known as the clean energy package, which aims to facilitate the transition to a clean energy economy, consists of eight legislative texts. One is directly related to renewable energythe Directive (EU) 2018/2001 of the European Parliament and of the Council, which was accepted on 11 December 2018. The Directive regulates the promotion of the use of energy from renewable sources, setting a binding Union target share of at least $32 \%$, to be reassessed by 2023 and increased if there are suitable economic and environmental conditions (such as cost reduction in generating activities, decarbonisation policies, and energy consumption) [60]. The elimination of specific national targets from previous Directives enables member states to set their own goals accordingly.

The target cannot be achieved without public and private investments. These investments should be supported by innovative and modern developments in all key sectors, facilitated by the Directive's guiding principles on financial support schemes. The support schemes should be designed according to the specific characteristics of renewable energy communities and must "provide incentives for the integration of electricity from renewable sources in the electricity market in a market-based and market-responsive way" (Article 4/2). The financial supports should be granted "in an open, transparent, competitive, non-discriminatory and cost-effective manner" (Article 4/4) [9].

The Directives also set principles for RES, self-consumption of renewable energy, energy communities, and district heating [61]. The elimination of administrative barriers is important for all investors, not only financial support schemes [62]. The Directive, therefore, promotes simplified administrative processes and cross borders cooperation among member states, as well as the use of renewable energy sources in transportation and heating and cooling sectors, and provides a framework for the right to self-consumption.

The member states are required to set proportionate and necessary national rules in keeping with energy efficiency principle (Art. 15) [9]. To overcome the problem of bureaucracy, seen as a potential barrier to these goals, fixed timeframes for all authorization, certification, and/or licensing procedures are to be implemented among national regulations.

The Directive established rules concerning:

- financial aid schemes for electricity produced from renewable sources (Art. 5, 6, 19);

- the self-consumption of this electricity (Art. 21);

- the use of energy from renewable sources in heating and cooling and in transport (Art. 23);

- regional cooperation between Member States and between Member States and third countries (Art. 3, 9, 11);

- guarantees of origin (Art 19);

- $\quad$ administrative procedures (Art. 15);

- information and training (Art. 18), in particular the establishment of certification or equivalent qualification systems for installers of biomass boilers and stoves, solar photovoltaic or thermal systems, surface geothermal systems and heat pumps of small size.

- reduction of greenhouse gas emissions for biofuels, bio liquids and fuels derived from biomass, proportionate according to the date of commissioning of the installations (Art. 25, 26, 29, 30, 31).

A key aspect of RED II is the introduction of the legal institution of "renewable energy communities" (REC).

Article 2/16 of RED II defined the renewable energy communities (REC) as a "legal entity:

a. which, in accordance with the applicable national law, is based on open and voluntary participation, is autonomous, and is effectively controlled by shareholders or members that are located in the proximity of the renewable energy projects that owned and developed by that legal entity;

b. the shareholders or members of which are natural persons, SMEs or local authorities, including municipalities; 
c. the primary purpose of which is to provide environmental, economic or social community benefits for its shareholders or members or for the local areas where it operates, rather than financial profits" [9].

The members of RECs should be residents close to renewable energy projects developed by the community. RECs can operate in all renewable energy markets. They can "produce, consume, store and sell renewable energy, including through renewables power purchase agreements" (Art. 22/1-a) [9]. However, REC activities are not limited to these, but extend to supplying energy or providing aggregation or other commercial energy services (Art. 22/4) [9].

In order to promote the existence of energy communities, all the regulatory barriers preventing people from joining should be removed.

Another legal institution introduced by RED II is the concept of renewable selfconsumers [62]. The renewable self-consumer is "a final customer who generates renewable electricity for their own consumption, and who may store or sell self-generated renewable electricity, provided that, for a nonhousehold renewables self-consumer, those activities do not constitute its primary commercial or professional activity" (Art. 2/14) [9].

Renewables self-consumers, individually or through aggregators, are entitled:

- " "to generate renewable energy, including for their own consumption, to store and sell their excess production of renewable electricity;

- $\quad$ to install and operate electricity storage systems;

- $\quad$ to maintain their rights and obligations as final consumers;

- $\quad$ to receive remuneration" (Art. 21/2) [9].

Renewable self-consumers located in the same building or multiapartment block are able to act jointly [48]. This is considered a type of self-consumer rather than a community by the Directive.

RED II included no provision on smart metering or data sharing. This shortcoming was remedied by the ED 2019.

\subsection{Internal Electricity Market Directive (ED 2019) 2019/944}

The aim of the internal electricity market regulations is to organize competitive electricity markets; to deliver choices for final customers; to provide "new business opportunities, competitive prices, efficient investment signals, and higher standards of service; and to contribute to the security of supply and sustainability" [10].

The Directives 96/92/EC [13], 2003/55/EC [63], and 2009/72/EC [64] (the previous directives on the internal electricity market) were designed to reach these goals, but all had shortcomings. The most recent directive, implemented for ten years, needed to be updated in line with developments. The Union's policy changed over these decades as decarbonisation increasingly became a priority [65]. The solution was ED 2019, accepted on 5 June 2019, on common rules for the internal market for electricity.

The Directive brought regulation on the "generation, transmission, distribution, supply, and storage of electricity together with consumer protection aspects, aiming to create integrated, competitive, consumer-centred, flexible, fair, and transparent electricity markets in the EU" [10].

The Directive gave special importance to customer rights, billing (Art. 18, 70, Annex I), aggregation (Art. 13,17), citizens' involvement in energy generation activities (Art. 16), access to data (Art. 20, 23, 24, 34, 61), electromobility clean energy (Art. 33), and new responsibilities for distribution and transmission system operators (Chapter IV and V) as well as national energy regulators [10]. Much importance was also given to the elimination of barriers and bureaucracy hindering the formation of energy communities [66].

The achievement of the free movement of goods, the freedom of establishment, and the freedom to provide services, as provided for in the Treaty on the Functioning of the European Union (TFEU) [67], depends on the involvement of citizens in the electricity market as consumers. People's right to generate electricity for their own use, i.e., selfgenerated electricity, was already recognized in most member States, but was underused 
because of the administrative and legal procedures and perceptions of risk and financial costs. Collective entrepreneurship was considered a possible solution, alongside the reduction of bureaucracy.

The Directive, therefore, introduced an important concept: the "citizen energy community" (CEC). The CEC is a parallel legal institution to the REC defined in RED II.

The CEC was defined by the Directive as a legal entity that (Art. 2/11) [10]:

a. "is based on voluntary and open participation and is effectively controlled by members or shareholders that are natural persons, local authorities, including municipalities, or small enterprises;

b. has for its primary purpose to provide environmental, economic or social community benefits to its members or shareholders or to the local areas where it operates rather than to generate financial profits; and

c. may engage in generation, including from renewable sources, distribution, supply, consumption, aggregation, energy storage, energy efficiency services or charging services for electric vehicles or provide other energy services to its members or shareholders".

The member states were required to remove all restrictions preventing CECs from accessing "electricity markets in a nondiscriminatory manner" (Art. 3/4, 16, 17).

Energy efficiency, the key principle in the EU's energy policy, was emphasized in this regulation [68]. As stated above, citizen involvement in the energy market is essential to energy efficiency and can be achieved only by facilitating the relevant procedures. Technology is a major tool in all steps, and the regulation prioritized the modernization of distribution networks through the introduction of smart grids and smart meters. The functionalities of smart metering systems were defined in detail in the Directive (Art. 20). The information collected would constitute big data, and emphasis was put on the management of this data (Art. 33, 34).

\section{Identifying the Concepts and Definitions of the Energy Communities according to RED II and ED 2019}

The Union's lean energy package priorities are moving from fossil fuels towards cleaner energy [59]. The Union is aware that without active involvement of all energy market stakeholders (including, and perhaps most importantly, customers) this target is unachievable. The two Directives mentioned above, therefore, prioritized the involvement of citizens with the electricity market as consumers and introduced the concept of energy communities. Two separate types of energy communities were defined by the two directives, namely, renewable energy communities and citizen energy communities. Despite similarities, some important-to-understand differences existed in the definitions.

\subsection{What Is a Renewable Energy Community?}

As noted in the previous paragraph, people's involvement in all levels of the energy market is key in achieving the targets set in RED II and ED 2019. It is almost impossible for an individual to compete with large-scale players unless united and given administrative, regulative, and financial support. The RED II clarified (in recital 63) that the development of the market for energy from renewable sources entirely depends on the positive impact of RECs. The shift from renewables needs local support from citizens and authorities, and RECs are expected to increase the participation in renewable energy projects and accelerate the transformation of the market.

RED II thus introduced a new legal entity, autonomous from individual members, that will give people the confidence to join the energy market, especially in generation for self-usage and distribution of the excess energy [69].

As discussed in Section 4.1, the RED II attempted to define the REC according to organization type, membership, and activities [26].

Individuals are free to join or establish RECs, but membership is not limited to natural persons. The participation of local authorities in a project has been found to inspire confidence and have a positive effect on participation. Local authorities, including 
municipalities, are therefore also counted among potential members/shareholders [70]. This strategy also contributes to local development and fulfilment of local needs.

The Directive's writers were aware that forced personal financial responsibilities would make people reluctant to participate in any new formation. RECs were therefore defined as legal entities that are autonomous/separate from individual members and other traditional market actors that participate in the community. The participation in REC is voluntary. It was also stated that being a REC member/shareholder would not affect the rights of people as final customers. The Directive avoided specifying an existing legal entity model for RECs, allowing the member states to choose the form that would best enable RECs to compete on an equal basis with existing energy market actors.

To promote local involvement, RECs should develop projects that are locally close to its members/shareholders.

RECs should not simply be set up as commercial companies primarily for financial profit but should work for the benefit of their members and the local area.

The principles on which energy communities should be based were regulated separately in Article 22 of RED II.

RECs have the authority to generate, store, consume, distribute, and sell energy [26,70]; i.e., they are free to operate in any aspect of the energy market. They can also share the energy generated with their members/shareholders, in conformity with their original purpose.

Clearly, RECs cannot achieve their expected goals without support from national energy policy. Member states, therefore, should eliminate all the barriers to the establishment and operation of RECs [19]. Public authorities should have adequate government support for the promotion of RECs. The cooperation of existing system operators is an important condition for RECs' survival in the energy market.

Any discriminatory or disproportionate action against RECs or their members/shareholders will negatively affect their existence, and therefore, RECs and their members/shareholders should receive fair, nondiscriminatory, proportionate, and transparent treatment from authorities $[69,71]$.

RECs will be most effective if every consumer has an equal opportunity to establish or join one, rather than membership being a privilege determined by level of income or some other quality.

\subsection{What Is a Citizen Energy Community?}

The policy of the internal market for electricity of the union promotes a competitive electricity market and aims to secure the supply and sustainability [10]. The tools created by previous directives on the internal electricity market to achieve targets needed updating to meet the last decade's goal of decarbonizing the energy system [65] and match technological developments. The security of supply and decent competitiveness can only be achieved with the active participation of all citizens. This involvement cannot occur without the elimination of all the barriers, at market entry, operation, and exit, for small-scale entrepreneurs. However, the removal of the barriers alone is not enough; small-scale entrepreneurs are financially incapable of competing with existing large-scale market players without financial support.

With all these concerns, ED 2019 recognized a new initiative under the name of "citizen energy community" (CEC) in which household customers are the primary actors.

As discussed in Section 4.2, ED 2019 attempted to define the CEC according to organization type, purpose of establishment, and activities [26]. As with RECs, participation in CECs is voluntary [70], and people are free to join and leave without losing their rights as consumers. CECs were initially thought of as a category of cooperation among local citizens; participation was therefore limited, and mid-range and large enterprises were excluded. The Directive stated that apart from natural persons, local authorities, including municipalities or small enterprises, may now also become CEC members or shareholders. The involvement of local authorities in CECs will have a positive effect on the fulfilment of 
local needs and local development and encourage citizen participation by building trust. The organization of CECs on these terms is the same as that of RECs.

The decision-making power in the CEC should belong to those members or shareholders for whom the energy sector does not constitute a primary area of economic activity. A citizen who was not involved in the energy sector would be reluctant to establish or join if given personal financial responsibility; CECs, therefore, were given the status of a legal entity exercising rights and subject to obligations in its own name.

The right to establish and join CECs does not affect the right to do business in the energy sector under private law instruments. It is therefore envisaged that CECs may take the form of any entity, whether already defined (e.g., cooperative, partnership, association), or newly created under national laws (recital 44) [10].

Unlike RECs, CECs' areas of activities are not limited to the electricity sector and renewable sources. They may generate, distribute, supply, consume, and store energy from all sources, or even provide related services such as electric vehicle charging.

It is important for energy market authorities to allow CECs to operate in the market under fair competition principles without facing discriminatory procedures $[6,69,71]$. CECs should (according to Art. 16.3) [10]:

- be "able to access all electricity markets, either directly or through aggregation, in a nondiscriminatory manner";

- be "treated in a non-discriminatory and proportionate manner with regard to their activities, rights, and obligations as final customers, producers, suppliers, distribution system operators, or market participants engaged in aggregation";

- $\quad$ share the electricity generated by the community with its members and shareholders without preventing their rights and obligations as final consumers.

Taking all these into the consideration, ED 2019 stated (Art. 16.1) that member states should "provide an enabling regulatory framework for citizen energy communities, ensuring that:

a. participation in a citizen energy community is open and voluntary;

b. members or shareholders of a citizen energy community are entitled to leave the community;

c. members or shareholders of a citizen energy community do not lose their rights or obligations as household customers or active customers;

d. relevant distribution system operators cooperate with citizen energy communities to facilitate electricity transfers within citizen energy communities;

e. citizen energy communities are subject to nondiscriminatory, fair, proportionate, and transparent procedures and charges, including with respect to registration and licensing, and to transparent, nondiscriminatory, and cost-reflective network charges" [10].

As access to a distribution network is essential for CEC operation, CECs "are entitled to own, establish, purchase, or lease distribution networks and to autonomously manage them" (Art. 16.1.(b)) and even become distribution system operators (recital 47) [10].

\subsection{Understanding the Differences between RECs and CECs}

The definition of the CEC resembles that of the REC, but with some differences $[61,70]$. As stated above, RECs have specific emphasis on renewable sources and should be located close to renewable energy projects, unlike a CEC. An energy community can only be called an REC if its activity is based on renewable energy sources, while a CEC may use renewable or conventional sources. A limitation of CECs is the dedication of their scope of activity to the electricity market, while RECs' area of activity may cover all aspects of the energy market, including electricity. The distinction between the two types of energy communities can be clearly seen in Table 2 . 
Table 2. Differences between CECs and RECs [72].

\begin{tabular}{ccc}
\hline Citizen Energy Community & Renewable Energy Community \\
\hline Members & $\begin{array}{c}\text { Natural persons, local authorities, } \\
\text { small/microenterprises }\end{array}$ & $\begin{array}{c}\text { Natural persons, local authorities, } \\
\text { small/microenterprises; with the } \\
\text { condition that the main professional } \\
\text { or commercial activity of the } \\
\text { members are not defined by their } \\
\text { membership to the REC }\end{array}$ \\
\hline Location & $\begin{array}{c}\text { No limitations on location, even } \\
\text { cross-border Citizen Energy } \\
\text { Communities can be established }\end{array}$ & $\begin{array}{c}\text { Members/shareholders need to be in } \\
\text { a specific location, close to the } \\
\text { associated project of the REC }\end{array}$ \\
\hline $\begin{array}{c}\text { Activities in the energy sector } \\
\text { targeted exclusively for members; } \\
\text { and activities exclusively in the } \\
\text { electricity sector for the whole } \\
\text { market }\end{array}$ & $\begin{array}{c}\text { All areas of the energy market } \\
\text { involving renewable energy }\end{array}$ \\
\hline Technologies & No limitation on technologies & Only renewable energy technologies \\
\hline
\end{tabular}

6. Analysing the Current Adoption of RED II and ED 2019 into National Legislation: Evidence from Austria, Germany, Greece, Italy, Spain, and Turkey

As intended, this manuscript aimed to provide an assessment concerning the adoption of RED II and ED 2019 into national legislation, along with the associated legal and administrative frameworks and other relevant factors. This was achieved by utilizing evidence from Austria, Germany, Greece, Italy, Spain, and Turkey.

These countries were selected as representing energy markets of varying size and maturity and reflecting different capacities and capabilities associated with transposing the directives into national legislation. In addition, including Turkey in this set also allowed assessment of the conformity and consistency of steps concerning the RED II and ED 2019 taken by a nonmember.

\subsection{Austria}

In Austria, energy market regulations are issued both by federal laws covering the country as a whole and by provincial laws covering specific geographical areas. The main Austrian electricity law is the Federal Act Providing New Rules for the Organization of the Electricity Sector (Electricity Act 2010) [73]. This act included provisions for the generation, transmission, distribution, and supply of electricity, as well as for the organization of the electricity industry. It also contained regulations on system charges and rules on billing, internal organization, unbundling, and transparency of accounting of electricity companies. Another key piece of legislation in renewable electricity is the Green Electricity Act 2012 [74], with regulations and subsidies for electricity from renewable sources. Two further important laws are the Natural Gas Sector Act 2011 [75] and the Federal Energy Efficiency Act [76]. The recent "Renewable Expansion Act" [77] also specified central requirements for the energy sector. There are regulations on RECs and new funding regulations for renewable forms of energy. With the amendment of the Electricity Act 2010, the legal requirements for the CEC were introduced. The Electricity Act 2010 additionally contained joint regulations for CECs and RECs. Therefore, both this law and the Renewable Expansion Act are the basis for the establishment and implementation of RECs and CECs.

Even before RECs and CECs, it was possible to share surplus electricity in Austria. Citizens are allowed to generate electricity for their own consumption and even sell the excess to neighbours. Citizens generating electricity themselves, wishing to sell surplus electricity to a neighbor through the public grid, shift from "consumers" to "providers" or "suppliers". The change in legal status means that the person must comply with the corresponding rights and obligations, i.e., the strict rules of the Electricity Act 2010. Moreover, if the sale activity does not meet the neighbour's whole electricity need, the 
neighbour might be forced to buy additional power from another provider/supplier. In order not to have to fulfill these obligations under electricity law, the citizen can sell their surplus electricity to an electricity supplier that, in turn, sells the electricity to the neighbor.

Austria is currently in the implementation phase of RED II and ED 2019. In the meantime, legal regulations on RECs and CECs have come into force.

The national regulations on RECs and CECs run parallel with those of RED II and ED 2019. An REC is permitted to generate energy from renewable sources, and to consume, store, or sell its self-generated energy. In addition, the community is allowed to be active in the field of aggregation and to provide other energy services. In Austria, a REC can use any renewable energy source, but the focus of the legal regulations is on electricity from renewable sources. Participation in an REC does not affect consumers' rights and obligations, in particular, the right to the free choice of supplier. The REC may entrust a third party for operation and management of its generation plant [26]. Contract and leasing models are also possible for RECs [78].

Members or shareholders of RECs (regardless of their used renewable energy source) can be:

- $\quad$ natural persons;

- municipalities;

- legal entities of public authorities (local departments and other legal bodies under public law); or

- $\quad$ small and medium enterprises.

RECs must be organized as associations, cooperative societies, or partnerships ("Offene Gesellschaft (OG)", "Kommanditgesellschaft (KG)“, "GmbH \& Co KG", respectively); corporations ("Aktiengesellschaft (AG)" or "Gesellschaft mit beschränkter Haftung $(\mathrm{GmbH})$ “); or similar associations with legal personality. RECs must consist of at least two members/shareholders [30]. Companies that do not meet the criteria for small and medium enterprises are excluded from participation in REC. There is no restriction for legal entities under public law, as there is for private companies [78]. In addition, there is another restriction for private companies-their participation must not represent their main commercial or professional activity, thus excluding the participation of electricity and natural gas companies. Their participation in a REC would be incompatible with the objective of the REC [78]. The REC's objective was formulated such that it corresponds to the German version of RED II. The objective of the REC must not be financial benefit; this must be clear from the company's chosen legal form or at least stated in its articles. The REC should primarily provide environmental, economic, or social benefit to the shareholders/members or to the local areas where the REC operates [77]. Participation is voluntary and open.

$\S 7$ no. 6a Electricity Act 2010 defined the CEC as a legal entity that generates, consumes, stores, or sells electrical energy, is active in the field of aggregation, or provides energy services to their members and is controlled by members or shareholders [26]. The definition already provides the framework for CECs, such as limitations on electricity, members, and control over the CEC.

By participating in a CEC, the rights and obligations of the individual members/shareholders remain unaffected, in particular, the free choice of suppliers [73]. The use of a different form of energy collectively is reserved for the RECs, as already stipulated by RED II and ED 2019. CECs can use any electricity, either renewable or fossil.

$\S 16 \mathrm{~d}(5)$ Electricity Act 2010 stipulated that the operating and controlling rights over generation facilities reside with the CEC. For operation and maintenance, the CEC can use a third party, such as a service provider or energy supply company [78].

The following possible members/shareholders of a CEC are envisaged:

- natural persons;

- legal entities; and

- local authorities. 
CECs are open to all types of legal entities in terms of membership, but the power of decision for these entities is restricted. To this end, the Electricity Act 2010 regulated in $\S 16 \mathrm{~b}(3)$ the types of members with the right to assert control over the CEC. Control is limited to natural persons, local authorities, and small enterprises [73]. This restriction of control applies automatically if chosen corporate form includes a statutory majority held by stated members/shareholders. According to the bill's explanatory notes, the necessity of limiting the power of control in CECs (as outlined above) derived from the open participation for all types of legal entities. The main decision-making powers were limited to members who are not engaged in large-scale commercial activities and whose actual area of business activity is not the energy industry. Thus, medium and large companies, as well as companies that are electricity undertakings [73], are excluded from control $[73,78]$. A community must consist of two or more members/shareholders. CECs must be organized as associations, cooperative societies, partnerships, corporations, or similar associations with legal personality, as in the case of RECs (see the discussion above).

Financial profit must not be a CEC's the main purpose; this must be clear from the chosen legal form of the company, or at least be stated in the company's statutes. The primary purpose of CECs is to provide members or the locality with environmental, economic, and social community benefits. In addition, participation is voluntary and open, as is leaving the community [79].

In addition to specific REC and CEC regulations, there are common regulations that are applicable to both communities. These regulations refer to the definition of how electricity is to be divided and which obligations the grid operator and the members of the communities have to fulfill. In addition, there are further regulations concerning the metering and billing of the shared electricity. Among other things, both energy communities are obliged to use a concessionary grid operator [73].

The Austrian implementation of RED II and ED 2019 is very closely based on the European requirements.

\subsection{Germany}

In Germany, there are two central laws in the field of energy: the Energy Act [80] and Renewable Energy Act 2021 [81]. The purpose of the Energy Act was to provide the public with the most secure, affordable, consumer-friendly, efficient, and environmentally sound grid-based supply of electricity and gas, increasingly based on renewable energy. The purpose of the 2021 Act was to enable the sustainable development of energy provision, mainly in the interest of climate and environmental protection, but it also aimed to reduce the economic costs of energy provision by including long-term external effects in order to conserve fossil energy resources and to promote technological development for the generation of electricity from renewable energies.

Early in 2021, an amendment to the Energy Act introduced adjustments to the Energy Act and the Renewable Energy Act 2021 (and other electricity provisions) as well as a further amendment to these laws (and other provisions). This modification focused on the implementation of the Electricity Market Directive 2019 (such as adjustments in the area of customers) and provisions on hydrogen in the Energy Act.

Under the existing regulations, there is no legal definition of RECs as contained in RED II, but there are regulations for "citizen energy corporations" [82] and a tenant electricity model [83]. The Renewable Energy Act 2021 also provided for a preferential grid connection for facilities that generate electricity from renewable energy, obliging the system operator to provide connection "without delay" and "with priority" [81].

Based on the amendment (Law of the Federal Ministry) that came into effect in January 2021, in Germany, there is no requirement to introduce a new legal entity in order to establish CECs, because a merger of citizens into legal entities is already possible (for example, a merger on the basis of a cooperative) [84]. In Germany, it should be noted, citizens have for some time had the right to form cooperatives to generate energy, based not on electricity law but on civil law provisions such as the Cooperative Act [85]. 
According to the amendment, active customers can offer products or services alone or bundled, directly or indirectly, as well as provide aggregators on a contractual basis. In this context, the German government pointed out various options already possible under German energy law, such as locally established and controlled power generation facilities [84]. To this end, the draft law included provisions such as the definition of aggregators [84] and their integration into the existing system; new regulations or adjustments in the area of end-user markets introduced in the Energy Act provide for the new role of consumers; and protection of their rights [84].

This amendment was drafted in 2020 and has been in force since 1.1.2021. It should be noted that there is currently no definition of CEC in German energy law, as there is in ED 2019.

For the implementation of the RED II in the area of renewable energy communities, the most relevant legislation is the existing regulation on "citizen energy corporations" (Bürgerenergiegesellschaften) in § 3 No. 16 Renewable Energy Act 2021. There was no need to introduce citizen energy companies in RED II, because this 2017 regulation already granted cooperatives meeting the prerequisites special preference in the field of onshore wind turbines (see legal definition below) $[81,86]$.

According to $\S 3$ No. 15 Renewable Energy Act 2021, a "citizen energy corporation" is any corporation:

- $\quad$ which consists of at least ten natural persons as voting members or voting shareholders;

- in which at least $51 \%$ of the voting rights are held by natural persons who have been registered with their principal residence (in accordance with $\S 21$ or $\S 22$ of the Federal Registration Act) for at least one year prior to the submission of the bid in the independent town (kreisfreie Stadt) or district (Landkreis) in which the planned onshore wind energy system is to be installed; and

- in which no member or shareholder of the corporation holds more than $10 \%$ of the voting rights in the corporation;

- whereby, in the case of a merger of several legal entities or partnerships into one corporation, it shall be enough if each member of the corporation fulfills requirements under subparagraphs (a) to (c).

This legal definition is related to $\S 36 \mathrm{~g}$ Renewable Energy Act 2021 [87]. In $\S 36 \mathrm{~g}$ (1) Renewable Energy Act 2021, special provisions provided are effective for bids for up to six onshore wind turbines with a maximum capacity of 18 megawatts. This encouragement of participation in renewable energy is in line with the legislature's aim to involve more wind energy facility operators [88]. This community effort is supported by the simplified bidding conditions for citizen energy corporations in relation to subsidies for onshore wind turbines [89].

The implementation process is incomplete, making it difficult to investigate differences between the implementation of the EU directives in Germany and directives themselves. The legislative amendments and draft laws implemented so far include no specific regulations on energy communities.

\subsection{Greece}

The energy policy of Greece was historically very conservative. All the market activities were strictly regulated, preventing people from generating their own electricity for self-consumption. The liberalization of the Greek energy market followed the same path as that of the EU [90].

Greek law 4001/2011 is the main legislation that regulates Greece's energy market [91]. This law is in conformity with previous EU energy packets, namely, the Directives 2009/72/EC [64] and 2009/73/EC [92]. One of the most important amendments during the last decade was law 4513/2018, introducing the concept of "energy communities" into Greek legislation [93]. The law was accepted on 23 January 2018 and was prepared taking into account the draft of the proposed EU Directive on RED II [94]. This made Greece the first EU country to have an official energy community definition in its legislation. According to Article 1 of the Law, energy communities are civil cooperatives designed with 
the following exclusive purposes: promoting social economy, solidarity, and innovation in the energy sector to reduce energy poverty; promoting energy sustainability; promoting production, storage, self-consumption, distribution, and supply of energy; enhancing energy self-sufficiency and security of island municipalities; improving end-use energy efficiency; and promoting the rational use of energy and sustainable transport.

Permitted members of ECs are natural and legal persons and some legal entities of public law, such as municipalities, communities, and prefectural self-governments [95] (OECD, 1997). A member's share cannot exceed more than $20 \%$ of the total capital. The majority of the members/shareholders of an energy community must be located near the headquarters of the EC.

According to the law, the activities an EC can carry out are as follows [93]:

- production, storage, self-consumption, or sale of energy;

- management, such as the collection, transport, treatment, storage, or disposal of raw materials for the production of energy;

- $\quad$ supply for members of energy products, appliances, and installations, with the aim of reducing energy consumption and improving energy efficiency;

- supply for members of electric vehicles and vehicles using alternative fuels in general;

- distribution of electricity within the region where it is located;

- development of network, management and exploitation of alternative fuel infrastructures;

- installation and operation of water desalination units using RES.

In addition to the above, ECs have the authority:

- to raise funds for the realization of investments for the exploitation of RES or CHP or interventions for the improvement of energy efficiency;

- to prepare studies on the utilization of RES or CHP;

- to implement energy efficiency improvement interventions or provision of technical support to members in the above areas;

- to manage or participate in programs funded by national or European Union resources;

- to advise on the management or participation of its members in programs funded by national or European Union resources;

- to inform, to educate, and to raise awareness at the local and regional levels on energy sustainability issues;

- to take actions to tackle energy poverty for vulnerable consumers or citizens below the poverty threshold, regardless of whether they are members of the energy community.

Law 4513/2018 omitted legislating the metering of the generated, distributed, or shared energy and the sharing of the necessary data with the EC. This shortcoming was remedied by the Ministerial Decree 15084/382 of 10 September 2019 [96].

Greek legislation did not distinguish between "citizen energy communities" and "renewable energy communities". Energy communities were given the right to be market players not only in the renewable energy market but in all energy sector areas. Accordingly, the definition of ECs in Greek laws is compatible with both EU Directives, RED II and ED 2019. This, however, constitutes a difference between the EU Directives and Greek legislation. Another difference is that Greece's legislation limits ECs' legal identification to cooperatives [97], in contrast to the EU Directives allowing the member states to recognize a broad range of existing forms of legal entities as energy communities.

As a result, one can conclude that, in the future, Greece may develop its energy community legislation to allow citizens to be part of other legal bodies besides cooperatives.

\subsection{Italy}

Italy has also updated its legislation and imported some of the regulations included in REDII. ED 2019, on the other hand, remains to be implemented by the Italian legislature.

The matter of renewable energy is governed by Legislative Decree n. 28/2011, which established the objectives and purposes of the energy policy [98]. This decree also provided administrative paths for the issue of permits to produce renewable energy and established 
certain economic incentives. Although the self-consumption model was allowed in Italy (by Legislative Decrees No. 79/1999 and 115/2008) [99,100], collective self-consumption was not possible until related legislation was updated on several occasions.

One important update took place in 2019 with Legislative Decree 162/19 (Decreto Milleproroghe) [101], converted into law on February 28, 2020 (Law no 8/2020) [102]. Art 42-bis of this Decree allowed consumers to collectively generate electricity from renewable sources for their own consumption, a regulation that makes a direct reference to article 21 paragraph 4 of the REDII. This type of collective self-consumption, however, only applies to residential buildings, tertiary sector buildings, industrial properties, or public administration buildings.

The same decree also regulated energy communities, stating that the shareholders or members of energy communities may be individuals, local authorities (including municipal administration), and small- and medium-sized enterprises for which participation in the community does not constitute the main commercial and industrial activity. Low-income families and vulnerable consumers are also encouraged join energy communities. The main objective of energy communities is to provide environmental, economic, or social benefits to its members or shareholders, or to the local areas in which the community operates. Financial profit cannot be a priority.

The current definition by the Italian regulatory context is the same as that of the REC introduced by RED II [9].

An energy plant established by an energy community in Italy should use renewable sources, and the power generated should not exceed $200 \mathrm{~kW}$ in either the collective selfconsumption or energy community methods. The energy generated may be shared using the existing distribution network. The members or shareholders of energy communities consuming the energy generated should be connected on low-voltage electrical networks.

In addition to the Legislative Decree 162/19, some regions adopted specific regulations on the subject, such as the regional law 3 August 2018, no. 12 of Piedmont [103]. The law defined and regulated energy communities. According to this regional law, energy communities are not-for-profit organizations able to generate and exchange energy from renewable energy sources rather than fossil fuels. They have the right to enter into agreements with the national electricity, gas, and water authority [103].

To date, ED 2019 has yet to be implemented by the Italian legislature, but a draft law (no. 1721) for harmonizing the Italian law with ED 2019 has been prepared [104]. The draft law required the Italian government to define and regulate citizen energy communities. The draft law, approved by the Senate Chamber on 29 October 2020, has been under examination by the Chamber of Deputies since 11 November 2020.

The Draft Law contained the delegation to the Government for the implementation of RED II, ED 2019, and Directive 2019/943. In particular, its Article 12 provided principles and guiding criteria for the implementation of ED 2019.

At present, the number of energy communities in Italy remains limited [105] while the interested actors, such as energy retailers, cooperatives, and municipalities, wait for the secondary legislation to clarify the regulatory and administrative framework.

Italy was the first European country to introduce electric smart meters on a large scale [106] for low-voltage end customers, and it still leads Europe in the number of electric energy smart meters in service. The regulations on smart metering systems require distribution companies, as operators of metering activities, to provide end customers with precise information on billing based on actual consumption and time bands of energy use.

\subsection{Spain}

The Spanish electricity sector is mainly regulated by the Law 24/2013 [107,108]. The goal of the Law was to establish a secure framework for the electricity sector, guarantee electricity supply of the required quality at the lowest cost, ensure the economic and financial sustainability of the system, and allow effective competition in the sector, all within the contemporary principles of environmental protection [109]. The Law also included regulations on 
self-consumption as an alternative source of electricity generation, defined as the consumption by one or more people of electrical energy from nearby production facilities with which they are associated (Art. 9). The regulations made by the Law were detailed in the Royal Decree 900/2015 [110]. The Decree explained the administrative, technical, and economic conditions to be applied to the self-consumption method. The definition of self-consumption conformed with that in the Law 24/2013 on Electricity Sector.

The right to participate in electricity generation was historically limited in Spain until the end of the last decade. Other than establishing a commercial company, people could participate only via self-consumption or establishing some form of cooperative [111]. Cooperatives, however, had no authority to generate electricity, only to distribute and market it.

Changes in the energy sector, the energy policy of the government, and EU legislation forced the government to issue the Royal Decree 15/2018 [112]. The Decree's importance was in introducing three fundamental principles to enable people to join self-consumption activities: (i) the recognition of the right to self-consume electricity without charges; (ii) the recognition of the right to shared (collective) self-consumption by one or more consumers to take advantage of economies of scale; and (iii) the principle of administrative and technical simplification, especially for small power installations [113]. The Royal Decree 244/2019, accepted the following year, regulated the administrative, technical, and economic conditions for the self-consumption of electrical energy [114]. Collective self-consumption was defined, according to this Decree, as a consumer group fed with electrical energy from nearby production facilities associated with it (Art. $3 / \mathrm{m}$ ).

The most recent significant legislative activity was initiated by the Royal Decree 23/2020 on 23 June 2020 [115], which introduced the term "renewable energy communities" into the Spanish legislation (Art. 4). The definition of RECs accepted by the Decree is the same as that in RED II.

Article 6 of the Law 24/2013 on the Electricity Sector defined RECs as legal entities that can generate, transport and distribute energy. The same article, on the other hand, carried separate definitions for the electric power producer, the market operator, the system operator, the carrier, distributor and the marketer. According to these definitions, only commercial companies can be given authority as a market operator, a system operator, or a carrier, whereas commercial companies and cooperative societies can be distributors or marketers. The legal entities of RECs were not included in this list, causing confusion over whether or not they are able to operate in these areas of the market. Since electric power generators may be natural or legal persons by definition, it is clear that RECs have the authority to generate electricity.

Spanish legislation seems in conformity with EU Directive REDII. The concept of "renewable energy community" was imported into Spanish legislation within two years of the acceptance of the Directive [115]. Clearly, further legislative actions are required to prevent any conflict of understanding arising from the definitions of market actors. Although the National Energy and Climate Plan of Spain for 2021-2030 proposed regulatory development to enable RECs to generate, consume, and sell renewable energy [116], the concept of the "citizen energy community" has yet to be imported into Spanish legislation. The National Energy and Climate Plan recognized this omission and sets goal for the introduction of CECs into legislation (measure 1.13).

\subsection{Turkey}

Turkey's energy legislation is largely regulated by the Act No. 6446 of 2013 on the Electricity Market [117]. This legislation was extended, in line with the EU Directive, by two laws: the Regulation on Unlicensed Electricity Generation in Electricity Market of 2019 [118] and Act No. 5346 of 2005 on Utilization of Renewable Energy Sources for the Purposes of Generating Electrical Energy [119].

Electricity generation and distribution can be carried out only by joint stock companies, limited liability companies (Art. 4/3), or organized industrial zones (OIZs) (Art. 7 and 
Art. 13) [117]. Electricity generation activity requires a licence from the Energy Market Regulatory Board. Article 14 of the Act stated that two market activities can be carried out without a licence: first, generation from facilities with a maximum of one megawatt power generation capacity based on renewable energy sources, and second, generation from facilities based on renewable energy resources with the limitation of contractual power in the connection agreement. Both exemptions allow consumers to generate electricity for their own consumption.

The main purpose of the Regulation on Unlicensed Electricity Generation in the Electricity Market of 2019 is to enable consumers to meet their electricity needs from their own generation facility, located as close as possible to the point of consumption [118]. The Regulation specified the administrative path for unlicensed electricity generation: the generation activity of natural persons and legal persons engaged in unlicensed electricity generation should be limited to their own needs (Art. 23); however, the surplus can be transferred to another consumption facility or facilities belonging to the same person if in the same distribution region. Article 29 of the Regulation also allowed the consumption aggregation method. One or more natural persons and/or legal persons in the same tariff group, either using the same connection point, or with electrical energy consumption that can be measured with a common meter, may establish generation facilities or facilities by aggregation of consumption (e.g., office block, shopping mall, and industrial estate). This demonstrates that collective self-consumption is possible under Turkish Law. The Regulation stated, however, that the person authorized for the relevant administrative procedures is also held legally responsible for administration of all participants, creating a negative effect on the application of the collective self-consumption method in Turkey.

Cooperatives are counted among the legal persons that can carry out generation through consumption aggregation in the Regulation (Art. 29). Since they have their own legal personalities, cooperatives, and not their members, take on the legal responsibilities arising from the legislation [120]. On the other hand, cooperatives are not exempt from the conditions for collective self-consumption. This means cooperatives can only be formed by persons using the same connection point or whose consumption can be measured from a single common meter [118]. This condition has limited the spread of cooperatives as energy communities in Turkey.

With no update of its energy legislation after the acceptance of relevant Directives of the EU, RED II and ED 2019, the concepts of RECs and CECs remain undefined in Turkish legislation. It should be concluded, therefore, that community-based collective generation in the form of a cooperative or a community without legal personality as in RECs/CECs is possible only for natural or legal persons in the same tariff group and with the same connection point, or for those for which the consumption can be measured with a single common meter.

Hence, while natural and legal persons are individually permitted (with administrative authorization) to generate electricity from renewable sources for personal consumption, their ability to do this collectively as RECs/CECs is limited by legislation. Communitybased collective generation in the form of a cooperative or a community without legal personality - as in RECs/CECs-is possible only for natural or legal persons in the same tariff group with the same connection point, or for those whose consumption can be measured with a single common meter. In practice, these conditions are valid only for organisations such as office blocks, shopping malls, and small industrial estates and not the majority of the population.

\subsection{Comparative Outlook}

A comparative analysis of the selected countries regarding RECs and CECs, involving the general outlook of the legal framework, the state of smart meter rollout and associated data flow in the selected countries is provided in the following Table 3. 


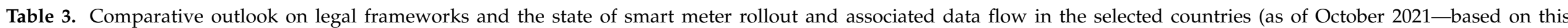
study's research).

\begin{tabular}{|c|c|c|c|c|}
\hline & REC/CEC & Community-Based Collective Generation & Smart Meters & Data Flow \\
\hline Austria & - $\quad$ RECs and CECs are defined & $\begin{array}{l}\text { - "Joint generation facilities" allow the residents of a build- } \\
\text { ing with several apartments or business premises to gen- } \\
\text { erate electricity with consumption aggregation }\end{array}$ & $\begin{array}{l}\text { - } \quad \text { Mostly implemented; } 95 \% \text { imple- } \\
\text { mentation expected by } 2022\end{array}$ & - $\quad$ Regulated and permitted \\
\hline Germany & $\begin{array}{l}\text { - Not defined, but community-based collective } \\
\text { generation is compatible with RECs/CECs to } \\
\text { a certain extent }\end{array}$ & $\begin{array}{l}\text { Tenant electricity model—citizens are free to install a } \\
\text { solar system on a residential building and share the } \\
\text { electricity with end customers } \\
\text { - Cooperatives are free to operate in the electricity market } \\
\text { Citizen energy corporations (a company established un- } \\
\text { der the existing company forms with special provisions) } \\
\text { are free to operate in the electricity market }\end{array}$ & $\begin{array}{l}\text { - } \quad \text { Mostly implemented } \\
\quad \text { Full implementation expected by } \\
2028\end{array}$ & - $\quad$ Regulated and permitted \\
\hline Greece & $\begin{array}{ll}\text { - } & \text { ECs are defined } \\
\text { - No distinction exists between RECs and CECs }\end{array}$ & - $\quad$ Possible in the form of ECs & $\begin{array}{l}\text { - } \quad \text { Legal infrastructure exists } \\
\text { - Ongoing implementation }\end{array}$ & - $\quad$ Regulated and permitted \\
\hline Italy & $\begin{array}{l}\text { - } \quad \text { Not defined } \\
\text { However, collective self-consumption regu- } \\
\text { lations are compatible with the definition of } \\
\text { RECs to a certain extent }\end{array}$ & $\begin{array}{l}\text { Small-scale collective self-consumption of renewable en- } \\
\text { ergy plants below } 200 \mathrm{~kW} \text { for customers linked to the } \\
\text { same low-voltage distribution subgrid }\end{array}$ & - Implemented on large scale & - $\quad$ Regulated and permitted \\
\hline Spain & $\begin{array}{l}\text { - } \quad \text { RECs are defined but need further secondary } \\
\text { legislation } \\
\text { - } \quad \text { CECs are not defined }\end{array}$ & $\begin{array}{l}\text { - } \quad \text { Collective self-consumption defined } \\
\quad \text { Cooperatives are allowed for limited activities }\end{array}$ & - Implemented & - $\quad$ Regulated and permitted \\
\hline Turkey & - $\quad$ Not defined & $\begin{array}{l}\text { - Very limited } \\
\text { Only possible for those who are in the same tariff group } \\
\text { and either connected to the same connection point or } \\
\text { having energy consumption measured with a single com- } \\
\text { mon meter }\end{array}$ & $\begin{array}{l}\text { - } \quad \text { Legal infrastructure exists } \\
\text { - Implementation is limited }\end{array}$ & - $\quad$ Regulated and permitted \\
\hline
\end{tabular}




\section{Conclusions}

Though RED II was introduced in 2018 and ED 2019 in 2019, analysis of the legal and administrative frameworks in selected countries revealed that none had yet completed the process of harmonizing their legislation concerning RECs and CECs. Hence, more progress is needed, at varying levels, for each country.

Of the countries studied, Germany had advantages in the process of adopting the directives into national legislation, since existing legislation already allowed individuals to participate in the electricity market. In Germany, citizen energy corporations allow for individual participation in electricity generation; therefore, a draft legislation outlining the current legal infrastructure explained that no further explicit definition of CECs was necessary. Greece also appears to have achieved relatively more progress among these countries. RED II came into effect in 2018, and in the same year, Greece introduced the concepts of energy communities in its national legislation, albeit without specific reference to RECs or CECs. Moreover, currently, the only possible form of energy community in Greece is energy cooperatives. Following Greece, Spain also amended the national legislation to incorporate the EU directives. Within Spain's legislation, RECs were explicitly defined, but there was no specific legal foundation for CECs. Moreover, RECs were not yet addressed in the main legislation concerning the electricity sector (Law 24/2013), causing discrepancies that hinder the development of REC initiatives. Austria introduced new legislation that covers the provisions of both RED II and ED 2019 during the first quarter of 2021, and in the third quarter, it issued regulations governing the establishment and operation of RECs and CECs, making it possible to generate and share electricity collectively. Italy and Turkey had taken no steps yet for incorporating the directives into national legislation.

For all selected countries, the national legislation included provisions that allowed individuals to produce electricity for self-consumption, but there were differences in the definition of community or collective electricity generation. Austria and Germany, for instance, had similar systems wherein the tenants of buildings or a group of apartments can produce electricity for consumption within their premises and sell any surplus to the market. For Turkey, such benefits were limited to groups for which consumption can be measured through the same single common meter (or, alternatively, sharing a common connection point) and were subject to the same tariff, and in practice, few households or commercial entities are able to meet either criterion. In Spain, electricity generation by communities was also primarily intended for self-consumption. For instance, apartment owners or industrial estate administrators may combine for collective electricity generation if in the same tariff group. For Italy, the threshold for the capacity of community electricity generation plants is $200 \mathrm{~kW}$, and the members should be connected to the same distribution subgrid. In Greece, the national legislation of 2018 permitted energy communities, and thus, community-based collective generation.

A more structured form of community energy generation is through energy cooperatives, which operated in many EU countries even prior to explicit references to RECs or CECs. In Germany, for instance, energy cooperatives can act as electricity market players without restrictions. Spain's more limited scope of action for energy cooperatives restricts eligibility for financial incentives, negatively impacting the development of energy cooperatives. In Italy, energy cooperatives cannot participate in the electricity market. The situation for Turkey was more positive from 2016 until 2019, when restrictions were placed on the activities of energy cooperatives, mainly in an attempt to prevent the abuse of financial support mechanisms. Only Austria has enacted regulations on RECs and CECs, making it possible for energy communities to be established and operate in the energy market.

The status of national implementations of REC and CEC requires further research, as full implementation has not yet occurred in most of the countries studied. As the paper shows, there are significant differences between REC and CEC, and individual countries, has at best, only partially implemented the differences, or even provided a legal basis for one of these two types of communities. After the implementation of RECs and CECs into 
national law, it will be necessary to examine how energy communities have integrated into the respective national energy markets and which resulting challenges and benefits are most evident.

Author Contributions: Conceptualization, M.E.B. and J.R.; Formal analysis, M.H.D., K.B., A.S. and E.F.; Funding acquisition, J.R.; Investigation, S.A.L., M.H.D. and K.B.; Methodology, M.E.B.; Project administration, J.R.; Writing-original draft, M.E.B., S.A.L., M.H.D. and K.B. All authors have read and agreed to the published version of the manuscript.

Funding: This research was funded by H2020 Executive Agency for Small and Medium-Sized Enterprises, grant number 890362.

Institutional Review Board Statement: Not applicable.

Informed Consent Statement: Not applicable.

Data Availability Statement: Not applicable.

Conflicts of Interest: The authors declare no conflict of interest.

\section{References}

1. Georgios, M.; Flouros, F. The Green Deal, National Energy and Climate Plans in Europe: Member States' Compliance and Strategies. Adm. Sci. 2021, 11, 75. [CrossRef]

2. European Commission. European Climate Pact. 2021. Available online: https://ec.europa.eu/clima/policies/eu-climate-action/ pact_en (accessed on 20 August 2021).

3. Hrncic, B.; Pfeifer, A.; Juric, F.; Duic, N.; Ivanovic, V.; Vusanovic, I. Different investment dynamics in energy transition towards a $100 \%$ renewable energy system. Energy 2021, 237, 121526. [CrossRef]

4. IRENA Website. Energy Transition. Available online: https://www.irena.org/energytransition (accessed on 20 August 2021).

5. Cunha, F.B.F.; Carani, C.; Nucci, C.A.; Castro, C.; Silva, M.S.; Torres, M.A. Transitioning to a low carbon society through energy communities: Lessons learned from Brazil and Italy. Energy Res. Soc. Sci. 2021, 75, 101994. [CrossRef]

6. Euroelectric. Citizens Energy Communities-Recommendations for a successful decarbonization. 2019. Available online: https: //www.apren.pt/contents/publicationsothers/eurelectric--citizens-energy-communities.pdf (accessed on 22 August 2021).

7. European Commission. Energy Communities. 2020. Available online: https://ec.europa.eu/energy/topics/markets-andconsumers/energy-communities_en (accessed on 25 August 2021).

8. European Commission. Clean Energy for All Europeans Package. Available online: https://ec.europa.eu/energy/topics/energystrategy/clean-energy-all-europeans_en (accessed on 22 August 2021).

9. Eur-Lex. Directive (EU) 2018/2001 of the European Parliament and of the Council of 11 December 2018 on the Promotion of the Use of Energy from Renewable Sources. Available online: https:/ / eur-lex.europa.eu/legal-content/EN/TXT/?uri=CELEX\%3A3 2018L2001 (accessed on 22 August 2021).

10. Eur-Lex. Directive (EU) 2019/944 of the European Parliament and of the Council of 5 June 2019 on Common Rules for the Internal Market for Electricity and Amending Directive 2012/27/EU. Available online: https:/ / eur-lex.europa.eu/legal-content/EN/ TXT/?uri=CELEX\%3A32019L0944 (accessed on 22 August 2021).

11. Leal-Arcas, R.; Akondo, N.; Rios, J.A. Energy Decentralization in the European Union. Georget. Environ. Law Rev. 2019, 32, 1042-1058.

12. Fehling, M. Energy Transition in the European Union and its Member States: Interpreting Federal Competence Allocation in the Light of the Paris Agreement. Transnatl. Environ. Law 2021, 10, 339-363. [CrossRef]

13. Eur-Lex. Directive 96/92/EC of the European Parliament and of the Council of 19 December 1996 Concerning Common Rules for the Internal Market in Electricity. Available online: https:/ / eur-lex.europa.eu/legal-content/EN/TXT/?uri=CELEX\%3A31996L0 092 (accessed on 28 September 2021).

14. Talus, K. Introduction to EU Energy Law; Oxford University Press: Oxford, UK, 2016; p. 4.

15. Martínez, F.C. The EU Energy Market Regulation Puzzle: Is There Still a Way Out? The Case for a Fourth Energy Package Along Completely Different Lines. Renew. Energy Law Policy Rev. 2014, 5, 121-129.

16. Park, P. International Law for Energy and the Environment, 2nd ed; CRC Press: Boca Raton, FL, USA, 2013 ; pp. 177-178.

17. Berka, A.; Dreyfus, M. Decentralisation and inclusivity in the energy sector: Preconditions, impacts and avenues for further research. Renew. Sustain. Energy Rev. 2021, 138, 1-7. [CrossRef]

18. Walker, G.; Hunter, S.; Devine-Wright, P.; Evans, B.; Fay, H. Harnessing Community Energies: Explaining and Evaluating Community-Based Localism in Renewable Energy Policy in the UK. Glob. Environ. Politics 2007, 7, 64-82. [CrossRef]

19. Verde, S.F.; Rosetto, N.; Ferrari, A.; Fonteneau, T. The Future of Renewable Energy Communities in the EU. An investigation at the Time of the Clean Energy Package. Research Report. 2020. Available online: https://cadmus.eui.eu/bitstream/handle/1814/68383 /QM-04-20-447-EN-N.pdf?sequence=1 (accessed on 29 September 2021). 
20. Reis, I.F.G.; Gonçalves, I.; Lopes, M.A.R.; Antunes, C.H. Business models for energy communities: A review of key issues and trends. Renew. Sustain. Energy Rev. 2021, 144, 111013. [CrossRef]

21. Bauwens, T.; Gotchev, B.; Holstenkamp, L. What drives the development of community energy in Europe? The case of wind power cooperatives. Energy Res. Soc. Sci. 2016, 13, 136-147. [CrossRef]

22. Huybrechts, B.; Mertens, S. The relevance of the cooperative model in the field of renewable energy. Ann. Public Coop. Econ. 2014, 85, 193-212. [CrossRef]

23. Van Der Horst, D. Social enterprise and renewable energy: Emerging initiatives and communities of practice. Soc. Enterp. J. 2008, 4, 171-185. [CrossRef]

24. Schreuer, A.; Weismeier-Sammer, D. Energy Cooperatives and Local Ownership in the Field of Renewable Energy Technologies: A Literature Review; Research Reports/RICC, 4; WU Vienna University of Economics and Business: Vienna, Austria, 2010; Available online: https:/ / epub.wu.ac.at/2897/1/Literature_Overview_energy_cooperatives_final_(2).pdf (accessed on 29 September 2021).

25. Walker, G.; Devine-Wright, P. Community renewable energy: What should it mean? Energy Policy 2008, 36, 497-500. [CrossRef]

26. Caramizaru, E.; Uihlein., A. Energy Communities: An Overview of Energy and Social Innovation; EUR 30083 EN; Publications Office of the European Union: Luxembourg, Luxembourg, 2020; Available online: https:/ / publications.jrc.ec.europa.eu/repository/ bitstream/JRC119433/energy_communities_report_final.pdf (accessed on 22 August 2021). [CrossRef]

27. Seyfang, G.; Park, J.J.; Smith, A. A thousand flowers blooming? An examination of community energy in the UK. Energy Policy 2013, 61, 977-989. [CrossRef]

28. Creamer, E.; Aiken, G.T.; van Veelen, B.; Walker, G.; Devine-Wright, P. Community renewable energy: What does it do? Walker and Devine-Wright (2008) ten years on. Energy Res. Soc. Sci. 2019, 57, 101223. [CrossRef]

29. Hicks, J.; Ison, N. An exploration of the boundaries of 'community' in community renewable energy projects: Navigating between motivations and context. Energy Policy 2018, 113, 523-534. [CrossRef]

30. Moroni, S.; Alberti, V.; Antoniucci, V.; Bisello, A. Energy Communities in a Distributed-Energy Scenario: Four Different Kinds of Community Arrangements. In Smart and Sustainable Planning for Cities and Regions; Bisello, A., Vettorato, D., Laconte, P., Costa, S., Eds.; Springer International Publishing: Cham, Switzerland, 2018; pp. 429-437. [CrossRef]

31. Moroni, S.; Alberti, V.; Antoniucci, V.; Bisello, A. Energy communities in the transition to a low-carbon future: A taxonomical approach and some policy dilemmas. J. Environ. Manag. 2019, 236, 45-53. [CrossRef]

32. Gancheva, M.; O’Brien, S.; Crook, N.; Monteiro, C. Models of Local Energy Ownership and the Role of Local Energy Communities in Energy Transition in Europe. A report for Commission for the Environment, Climate Change and Energy-European Committee of the Regions. Available online: https:/ / cor.europa.eu/en/engage/studies/Documents/local-energy-ownership.pdf (accessed on 25 September 2021).

33. Wuebben, D.; Romero-Luis, J.; Gertrudix, M. Citizen Science and Citizen Energy Communities: A Systematic Review and Potential Alliances for SDGs. Sustainability 2020, 12, 10096. [CrossRef]

34. Krug, M.; Di Nucci, M.R. Citizens at the heart of the energy transition in Europe? Opportunities and challenges for community wind farms in six European countries. Renew. Energy Law Policy Rev. 2020, 9, 9-27.

35. Gjorgievski, V.Z.; Cundeva, S.; Georghiou, G.E. Social arrangements, technical designs and impacts of energy communities: A review. Renew. Energy 2021, 169, 1138-1156. [CrossRef]

36. Capellán-Pérez, I.; Campos-Celador, Á.; Terés-Zubiaga, J. Renewable Energy Cooperatives as an instrument towards the energy transition in Spain. Energy Policy 2018, 123, 215-229. [CrossRef]

37. Wierling, A.; Schwanitz, V.J.; Zeiß, J.P.; Bout, C.; Candelise, C.; Gilcrease, W.; Gregg, J.S. Statistical Evidence on the Role of Energy Cooperatives for the Energy Transition in European Countries. Sustainability 2018, 10, 3339. [CrossRef]

38. Gui, E.M.; MacGill, I. Typology of future clean energy communities: An exploratory structure, opportunities, and challenges. Energy Res. Soc. Sci. 2018, 35, 94-107. [CrossRef]

39. Dóci, G.; Vasileiadou, E. "Let's do it ourselves" Individual motivations for investing in renewables at community level. Renew. Sustain. Energy Rev. 2015, 49, 41-50. [CrossRef]

40. Soeiro, S.; Dias, M.F. Renewable energy community and the European energy market: Main motivations. Heliyon 2020,6 , e04511. [CrossRef]

41. Berka, A.L.; Creamer, E. Taking stock of the local impacts of community owned renewable energy: A review and research agenda. Renew. Sustain. Energy Rev. 2018, 82, 3400-3419. [CrossRef]

42. Bauwens, T. Analyzing the determinants of the size of investments by community renewable energy members: Findings and policy implications from Flanders. Energy Policy 2019, 129, 841-852. [CrossRef]

43. Bomberg, E.; McEwen, N. Mobilizing community energy. Energy Policy 2012, 51, 435-444. [CrossRef]

44. Bamberg, S.; Rees, J.; Seebauer, S. Collective climate action: Determinants of participation intention in community-based pro-environmental initiatives. J. Environ. Psychol. 2015, 43, 155-165. [CrossRef]

45. Heldeweg, M.A.; Saintier, S. Renewable energy communities as 'socio-legal institutions': A normative frame for energy decentralization? Renew. Sustain. Energy Rev. 2020, 119, 109518. [CrossRef]

46. van Bommel, N.; Höffken, J.I. Energy justice within, between and beyond European community energy initiatives: A review. Energy Res. Soc. Sci. 2021, 79, 102157. [CrossRef]

47. Hanke, F.; Guyet, R.; Feenstra, M. Do renewable energy communities deliver energy justice? Exploring insights from 71 European cases. Energy Res. Soc. Sci. 2021, 80, 102244. [CrossRef] 
48. Milčiuvienè, S.; Kiršienè, J.; Doheijo, E.; Urbonas, R.; Milčius, D. The Role of Renewable Energy Prosumers in Implementing Energy Justice Theory. Sustainability 2019, 11, 5286. [CrossRef]

49. Diekmann, J.; Breitschopf, B.; Lehr, U. Social Impacts of Renewable Energy in Germany: Size, History and Alleviation. GWS Discussion Paper 2016/07. Available online: https:/ /www.gws-os.com/discussionpapers/gws-paper16-7.pdf (accessed on 25 September 2021).

50. Kracher, A. Renewable Energy Communities Exploring Behavioral and Motivational Factors Behind the Willingness to Participate in Renewable Energy Communities in Germany. Master's Thesis, Lund University, Lund, Sweden, May 2021.

51. Curtin, J.; McInerney, C.Ó.; Gallachóir, B. Financial incentives to mobilise local citizens as investors in low-carbon technologies: A systematic literature review. Renew. Sustain. Energy Rev. 2017, 75, 534-547. [CrossRef]

52. Bray, R.; Woodman, B.; Connor, P. Policy and Regulatory Barriers to Local Energy Markets in Great Britain; EPG Working Paper: EPG 1801; University of Exeter: Exeter, UK, 2018; Available online: http:/ /geography.exeter.ac.uk/media/universityofexeter/ schoolofgeography/images/researchgroups/epg/09.05.18_Policy_and_Regulatory_Barriers_to_LEMs_in_GB_BRAY_pdf (accessed on 26 September 2021).

53. d'Herbemont, S.; Roberts, J.J. Final Report on Best Practices and Legal Barriers for Supplying REScoops and Promoting Energy Efficiency. Deliverable D6.3, REScoop PLUS Project. 2019. Available online: https:/ / uploads.strikinglycdn.com/files/257ad1dc44ce-4ff6-9710-42c8afa0ca91/6.3\%20FINAL\%20V3-merged.pdf?id=158162 (accessed on 26 September 2021).

54. Wagemans, D.; Scholl, C.; Vasseur, V. Facilitating the Energy Transition-The Governance Role of Local Renewable Energy Cooperatives. Energies 2019, 12, 4171. [CrossRef]

55. d'Herbemont, S.; Roberts, J.J. Analysis of the Legal Environment at the EU Level. Deliverable D6.1, REScoop PLUS Project. 2019. Available online: https:/ / uploads.strikinglycdn.com/files/3530d1b2-0b68-4b2b-a229-56a0635aecdd/D6.1\%20Analysis\%20of\% 20the\%20Legal\%20Environment\%20at\%20the\%20EU\%20level.pdf?id=152677 (accessed on 26 September 2021).

56. Weber, L. Some reflections on barriers to the efficient use of energy. Energy Policy 1997, 25, 833-835. [CrossRef]

57. Brummer, V. Community energy—benefits and barriers: A comparative literature review of Community Energy in the UK, Germany and the USA, the benefits it provides for society and the barriers it faces. Renew. Sustain. Energy Rev. 2018, 94, 187-196. [CrossRef]

58. Palm, J. Energy Communities in Different National Settings-Barriers, Enablers and Best Practices. Deliverable 3.3 of New Clean Energy Communities in a Changing European Energy System (NEWCOMERS) Project. 2020. Available online: https: / / www.newcomersh2020.eu/upload/files/Deliverable\%203_3_\%20Energy \%20communities\%20in\%20different \%20 national\%20settings_barriers\%2C\%20enablers\%20and\%20best\%20practices.pdf (accessed on 28 September 2021).

59. Nouicer, A.; Kehoe, A.M.; Nysten, J.; Fouquet, D.; Hancher, L.; Meeus, L. The EU Clean Energy Package; European University Institute: Fiesole, Italy, 2020.

60. Kulovesi, K.; Oberthür, S. Assessing the EU's 2030 Climate and Energy Policy Framework: Incremental change toward radical transformation? Rev. Eur. Comp. Int. Environ. Law 2020, 29, 151-166. [CrossRef]

61. Frieden, D.; Tuerk, A.; Roberts, J.; d'Herbemont, S.; Gubina, A. Collective Self-Consumption and Energy Communities: Overview of Emerging Regulatory Approaches in Europe. Working Paper (Compile). 2019. Available online: https://www.compile-project.eu/wpcontent/uploads/COMPILE_Collective_self-consumption_EU_review_june_2019_FINAL-1.pdf (accessed on 22 August 2021).

62. Jasiak, M. Energy communities in the clean energy package. Eur. Energy J. 2018, 8, $29-39$.

63. Eur-Lex. Directive 2003/55/EC of the European Parliament and of the Council of 26 June 2003 Concerning Common Rules for the Internal Market in Natural Gas and Repealing Directive 98/30/EC. Available online: https:/ / eur-lex.europa.eu/legal-content/ EN/TXT/?uri=celex\%3A32003L0055 (accessed on 22 August 2021).

64. Eur-Lex. Directive 2009/72/EC of the European Parliament and of the Council of 13 July 2009 Concerning Common Rules for the Internal Market in Electricity and Repealing Directive 2003/54/EC. Available online: https:/ / eur-lex.europa.eu/legal-content/ EN/ALL/?uri=celex\%3A32009L0072 (accessed on 22 August 2021).

65. Dupont, C.; Oberthür, S. Decarbonization in the EU: Setting the Scene. In Decarbonization in the European Union. Energy, Climate and the Environment; Dupont, C., Oberthür, S., Eds.; Palgrave Macmillan: London, UK, 2015; pp. 154-196. [CrossRef]

66. Sokołowski, M.M. Renewable and citizen energy communities in the European Union: How (not) to regulate community energy in national laws and policies. J. Energy Nat. Resour. Law 2020, 38, 289-304. [CrossRef]

67. Eur-Lex. Consolidated Version of the Treaty on the Functioning of the European Union. Available online: https://eur-lex.europa. $\mathrm{eu} /$ legal-content/EN/TXT/?uri=celex\%3A12012E\%2FTXT (accessed on 22 August 2021).

68. Román-Collado, R.; Economidou, M. The role of energy efficiency in assessing the progress towards the EU energy efficiency targets of 2020: Evidence from the European productive sectors. Energy Policy 2021, 156, 112441. [CrossRef]

69. Lowitzsch, J.; Hoicka, C.E.; van Tulder, F.J. Renewable energy communities under the 2019 European Clean Energy PackageGovernance model for the energy clusters of the future? Renew. Sustain. Energy Rev. 2020, 122, 109489. [CrossRef]

70. Roberts, J.; Frieden, D.; d'Herbemont, S. Energy Community Definition, Explanatory Note (Compile). 2019. Available online: https:/ / www.compile-project.eu/wp-content/uploads/Explanatory-note-on-energy-community-definitions.pdf (accessed on 22 August 2021).

71. Sokolowski, M.M. European Law on the Energy Communities: A Long Way to a Direct Legal Framework. Eur. Energy Environ. Law Rev. 2018, 27, 60-70. 
72. Council of European Energy Regulators, Report on Regulatory Aspects of Self Consumption and Energy Communities. 2019. Available online: https:/ / www.ceer.eu/documents/104400/-/- /8ee38e61-a802-bd6f-db27-4fb61aa6eb6a (accessed on 21 September 2021).

73. Bundesgesetz, mit dem die Organisation auf dem Gebiet der Elektrizitätswirtschaft neu Geregelt Wird (Elektrizitätswirtschafts- und -Organisationsgesetz 2010_ElWOG 2010). F.L.G. I No. 110/2010 last amended by F.L.G. I No. 150/2021.. Available online: https: //www.ris.bka.gv.at/GeltendeFassung.wxe?Abfrage=Bundesnormen\&Gesetzesnummer=20007045 (accessed on 22 August 2021).

74. Bundesgesetz über die Förderung der Elektrizitätserzeugung aus Erneuerbaren Energieträgern (Ökostromgesetz 2012-ÖSG 2012). F.L.G I No. 75/2011 Last Amended by F.L.G I No. 150/2021. Available online: https:/ / www.ris.bka.gv.at/GeltendeFassung. wxe? Abfrage=Bundesnormen\&Gesetzesnummer=20007386 (accessed on 22 August 2021).

75. Bundesgesetz, mit dem Neuregelungen auf dem Gebiet der Erdgaswirtschaft Erlassen Werden (Gaswirtschaftsgesetz 2011GWG 2011). F.L.G. I No. 107/2011 Last Amended by F.L.G. I No. 150/2021. Available online: https://www.ris.bka.gv.at/ GeltendeFassung.wxe?Abfrage=Bundesnormen\&Gesetzesnummer=20007523 (accessed on 22 August 2021).

76. Bundesgesetz über die Steigerung der Energieeffizienz bei Unternehmen und dem Bund (Bundes-Energieeffizienzgesetz-EEffG). F.L.G. I No. 72/2014 Last Amended by F.L.G. I No. BGBl. I Nr. 68/2020. Available online: https://www.ris.bka.gv.at/ GeltendeFassung.wxe?Abfrage=Bundesnormen\&Gesetzesnummer=20008914 (accessed on 22 August 2021).

77. Bundesgesetz über den Ausbau von Energie aus erneuerbaren Quellen (Erneuerbaren-Ausbau-Gesetz-EAG). F.L.G. I 150/2021. Available online: https://www.ris.bka.gv.at/Dokumente/RegV/REGV_COO_2026_100_2_1842895/REGV_COO_2026_100_2 _1842895.pdf (accessed on 22 August 2021).

78. Parlament Republik Österreich, 733 der Beilagen XXVII. GP—Regierungsvorlage—Erläuterungen. Available online: https: / /www.parlament.gv.at/PAKT/VHG/XXVII/I/I_00733/fname_933186.pdf (accessed on 22 August 2021). (In German).

79. Cejka, S. Energiegemeinschaften im Clean Energy Package der EU. 2020. Available online: https://www.researchgate.net/ publication/340548396_Energiegemeinschaften_im_Clean_Energy_Package_der_EU (accessed on 22 August 2021). (In German).

80. Gesetz über die Elektrizitäts- und Gasversorgung (Energiewirtschaftsgesetz-EnWG) Energiewirtschaftsgesetz from 7. July 2005 (F.L.G. I p. 1970, 3621). Available online: https:/ /www.gesetze-im-internet.de/enwg_2005/ (accessed on 22 August 2021). (In German).

81. Gesetz für den Ausbau Erneuerbarer Energien (Erneuerbare-Energien-Gesetz-EEG 2021) Erneuerbare-Energien-Gesetz from 21 July 2014. (F.L.G. I p. 1066). Available online: https:/ /www.gesetze-im-internet.de/eeg_2014/ (accessed on 22 August 2021). (In German).

82. Website of Bundesnetzagentur. Available online: https://www.bundesnetzagentur.de/DE/Sachgebiete/ElektrizitaetundGas/ Unternehmen_Institutionen/Ausschreibungen/Wind_Onshore/Buergerenergiegesellschaften/Buergerenergiegesell_node. html (accessed on 28 August 2021).

83. Website of Bundesnetzagentur. Available online: https://www.bundesnetzagentur.de/DE/Sachgebiete/ElektrizitaetundGas/ Unternehmen_Institutionen/ErneuerbareEnergien/EEGAufsicht/Mieterstrom/Mieterstrom_node.html (accessed on 28 May 2021).

84. Draft Law of Federal Ministry of Economic Affairs and Energy Submitted to the German Parliament. Available online: https: / / dip21.bundestag.de/dip21/btd/19/274/1927453.pdf (accessed on 28 April 2021). (In German).

85. Genossenschaftsgesetz in the Version of the Announcement of 16 October 2006. (F.L.G. I p. 2230). Available online: https: //www.gesetze-im-internet.de/geng/ (accessed on 22 August 2021). (In German).

86. Vollprecht, J.; Lehnert, W.; Kather, N. Die neue Erneuerbare-Energien-Richtlinie (RED II): Steife Brise oder laues Lüftchen aus Europa? ZUR Z. Für Umweltr. 2020, 31, 204-215. (In German)

87. Lülsdor, T. Die neuen Ausschreibungen nach dem EEG 2017 Einführung und Überblick. In Energierecht; Theobald, C., Kühling, J., Eds.; C.H. Beck: München, Germany, 2020; Volume 108, pp. 45-52. (In German)

88. Hakenberg, M. Bürgerenergiegesellschaften. In Rechtswörterbuch; Weber, K., Aichberger, T., Eds.; C.H. Beck: München, Germany, 2021; Volume 24. (In German)

89. Schulz, T.; Losch, R. Die geplante Neufassung der Erneuerbare-Energien-Richtlinie. EnWZ 2017, 6, 107-114.

90. Vlados, C.; Chatzinikolaou, D.; Kapaltzoglou, F. Energy market liberalisation in Greece: Structures, policy and prospects. Int. J. Energy Econ. Policy 2021, 11, 115-126. [CrossRef]

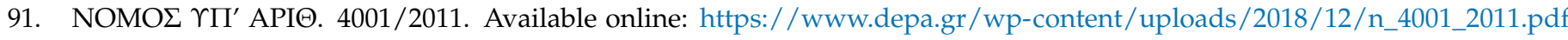
(accessed on 22 August 2021). (In Greek).

92. Eur-Lex. Directive 2009/73/EC of the European Parliament and of the Council of 13 July 2009 Concerning Common Rules for the Internal Market in Natural Gas and Repealing Directive 2003/55/EC. Available online: https: / / eur-lex.europa.eu/legal-content/ EN/ALL/?uri=CELEX\%3A32009L0073 (accessed on 22 August 2021).

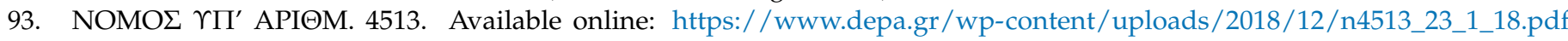
(accessed on 22 August 2021). (In Greek).

94. Douvitsa, I. The New Law on Energy Communities in Greece. 2019. Available online: https://revistas.webs.uvigo.es/index.php/ CES/article/view/1385/1367 (accessed on 22 August 2021).

95. OECD. Managing Across Levels of Government Greece. Available online: https://www.oecd.org/gov/budgeting/1902362.pdf (accessed on 22 August 2021). (In Greek).

96. АПОФА $\Sigma Е І \Sigma$ А metering_Storage_Mar2019.pdf (accessed on 22 August 2021). (In Greek).

97. Tsagkari, M. How Greece undermined the idea of renewable energy communities: An overview of the relevant legislation. Law Environ. Dev. J. 2021, 17, 85-91. 
98. Gazzetta Ufficiale Della Repubblica Italiana. Decreto Legislativo 3 Marzo 2011, n. 28. Available online: https://www. gazzettaufficiale.it/eli/id/2011/03/28/011G0067/sg (accessed on 22 August 2021). (In Italian).

99. Gazzetta Ufficiale Della Repubblica Italiana. Decreto Legislativo 16 Marzo 1999, n. 79. Available online: https://www. gazzettaufficiale.it/eli/id/1999/03/31/099G0136/sg (accessed on 22 August 2021). (In Italian).

100. Normattiva, Decreto Legislativo 30 Maggio 2008, n. 115. Available online: https://www.normattiva.it/uri-res/N2Ls?urn:nir: stato:decreto.legislativo:2008;115 (accessed on 22 August 2021). (In Italian).

101. Gazzetta Ufficiale Della Repubblica Italiana. Decreto Legislativo 30 Dicembre 2019, n. 162, n. 79. Available online: https: / / www.gazzettaufficiale.it/eli/id/2019/12/31/19G00171/sg (accessed on 22 August 2021). (In Italian).

102. Gazzetta Ufficiale Della Repubblica Italiana. Decreto Legge 8 Aprile 2020, n. 23. Available online: https:/ / www.gazzettaufficiale it/eli/gu/2020/04/08/94/sg/pdf (accessed on 22 August 2021). (In Italian).

103. Mutani, G.; Todeschi, V.; Tartaglia, A.; Nuvoli, G. Energy Communities in Piedmont Region (IT). The Case Study in Pinerolo Territory. In Proceedings of the IEEE International Telecommunications Energy Conference, Turino, Italy, 7-11 October 2018; pp. 1-8. [CrossRef]

104. Ghezzi, P.; Scarduelli, P.; Alpigiani, M. Implementation of EU Directive on Unfair Trading Practices in B2B Relationships in the Agricultural and Food Supply Chain is Approaching. Available online: https:/ / www.lexology.com/library/detail.aspx?g=d2ae0 0dd-95fd-4015-b4e1-a146caa79d4d (accessed on 22 August 2021).

105. Candelise, C.; Ruggieri, G. Status and Evolution of the Community Energy Sector in Italy. Energies 2020, 13, 1888. [CrossRef]

106. Pitì, A.; Bettenzoli, E.; De Min, M.; Lo Schiavo, L. Smart Metering: An Evolutionary Perspective. Paper prepared as application to 2016 ERRA Award. 2016. Available online: https://erranet.org/wp-content/uploads/2017/09/Highly-Acknowledged-Paper_ PitiTeam_Paper_Award_2017.pdf (accessed on 22 August 2021).

107. Agencia Estatal Boletín Oficial del Estado, Ley 24/2013, de 26 de Diciembre, del Sector Eléctrico. Available online: https: / / www.boe.es/buscar/doc.php?id=BOE-A-2013-13645 (accessed on 22 August 2021). (In Spanish).

108. Bassas, I. Renewable Energy in Spain: Additional Remuneration and Other Issues. Renew. Energy Law Policy Rev. 2016, 7, 180-183.

109. Driha, O.M.; López-Milla, J.; Sevilla-Jiménez, M. The Spanish Energy Policy Roller Coaster within the European Union: A Spotlight on Renewables. In Analysis of Energy Systems; Bianco, V., Ed.; CRC Press: Boca Raton, FL, USA, 2017 ; pp. $265-291$.

110. Agencia Estatal Boletín Oficial del Estado, Real Decreto 900/2015, de 9 de Octubre, por el Que se Regulan las Condiciones Administrativas, Técnicas y Económicas de las Modalidades de Suministro de Energía Eléctrica con Autoconsumo y de Producción con Autoconsumo. Available online: https:/ / www.boe.es/buscar/doc.php?id=BOE-A-2015-10927 (accessed on 22 August 2021). (In Spanish).

111. Heras-Saizarbitoria, I.; Sáez, L.; Allur, E.; Morandeira, J. The emergence of renewable energy cooperatives in Spain: A review. Renew. Sustain. Energy Rev. 2018, 94, 1036-1043. [CrossRef]

112. Agencia Estatal Boletín Oficial del Estado. Real Decreto-ley 15/2018, de 5 de Octubre, De Medidas Urgentes para la Transición Energética y la Protección de los Consumidores. Available online: https://www.boe.es/buscar/doc.php?id=BOE-A-2018-13593 (accessed on 22 August 2021). (In Spanish).

113. Insights, The main novelties of the Royal Decree Law 15/2018, 5 October, on Urgent Measures for the Energy Transition and the Protection of Consumers. Available online: https:/ /www.osborneclarke.com/insights/the-main-novelties-of-the-royal-decree-law-15 2018-5-october-on-urgent-measures-for-the-energy-transition-and-the-protection-of-consumers / (accessed on 22 August 2021).

114. Agencia Estatal Boletín Oficial del Estado. Real Decreto 244/2019, de 5 de Abril, Por el que se Regulan las Condiciones administrativas, Técnicas y Económicas del Autoconsumo de Energía Eléctrica. Available online: https://www.boe.es/diario_ boe/txt.php?id=BOE-A-2019-5089 (accessed on 22 August 2021). (In Spanish).

115. Agencia Estatal Boletín Oficial del Estado. Real Decreto-ley 23/2020, de 23 de Junio, Por el que se Aprueban Medidas en Materia de Energía y en Otros Ámbitos para la Reactivación Económica. Available online: https:/ / www.boe.es/buscar/act.php?id=BOEA-2020-6621 (accessed on 22 August 2021). (In Spanish).

116. European Commission. Integrated National Energy and Climate Plan 2021-2030. Available online: https:/ / ec.europa.eu/energy/ sites/default/files/documents/es_final_necp_main_en.pdf (accessed on 22 August 2021).

117. Cumhurbaskanligi Mevzuat Bilgi Sistemi, Elektrik Piyasasi Kanunu. Available online: https://www.mevzuat.gov.tr/ MevzuatMetin/1.5.6446.pdf (accessed on 22 August 2021). (In Turkish)

118. Resmi Gazete, Elektrik Piyasasında Lisanssız Elektrik Üretimi Yönetmeliği. Available online: https://www.resmigazete.gov.tr/ eskiler/2019/05/20190512-1.htm (accessed on 22 August 2021). (In Turkish)

119. Cumhurbaskanligi Mevzuat Bilgi Sistemi, Yenilenebilir Enerji Kaynaklarının Elektrik Enerjisi Üretim Amaçlı Kullanıma İlişkin Kanun. Available online: https:/ / www.mevzuat.gov.tr/MevzuatMetin/1.5.5346.pdf (accessed on 22 August 2021). (In Turkish)

120. Coşkun, M. Kooperatifler Hukuku; Seçkin Yayınevi: Ankara, Turkey, 2019. 